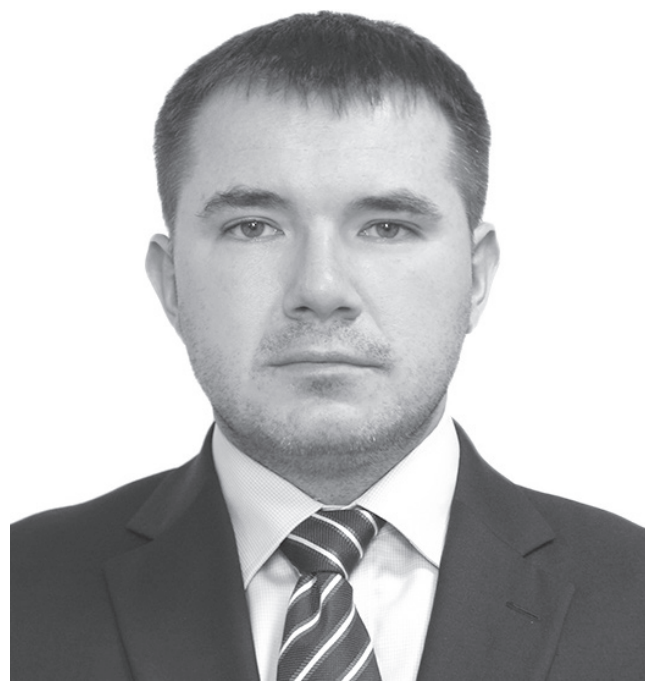

Bliznuk Andrii Stanislavovich, Candidate of science in Public Administration, doctoral student of the Interregional Academy of Personnel Management, 01042, Kyiz, Str. Frometivska, 2, tel.: +38 (095) 45217 71, e-mail: abliznyuk1986@gmail.com

ORCID: 0000-0001-8768-5177

DOI: $10.32689 / 2617-2224-2018-15-5-42-52$
Близнюк Андрій Станіславович, кандидат наук з державного управління, докторант кафедри публічного адміністрування, Міжрегіональна Академія управління персоналом, 01042, Київ, вул. Фрометівська, 2, тел.: +38 (095) 45217 71,e-mail:abliznyuk1986@gmail.com ORCID: 0000-0001-8768-5177

\section{Близнюк Андрей Станиславович,} кандидат наук по государственному управлению, докторант кафедры публичного администрирования, Межрегиональная Академия управления персоналом, 01042, Киев, ул. Фрометовская, 2, тел.: +38 (095) 45217 71, e-mail: abliznyuk1986@gmail.com

ORCID: 0000-0001-8768-5177

\title{
ОСОБЛИВОСТІ ІНСТИТУЦІЙНОГО ЗАБЕЗПЕЧЕННЯ МЕХАНІЗМІВ ДЕРЖАВНОГО РЕГУЛЮВАННЯ РОЗВИТКУ РЕКРЕАЦІЙНОЇ СФЕРИ
}

Анотація. Систематизовано та уточнено теоретичні основи дослідження інституційного забезпечення механізмів державного регулювання розвитку рекреаційної сфери.

Інституційну підтримку сектору рекреації формують державні та неурядові організаційні структури, створені на різних рівнях механізму, та реалізують свої рішення за допомогою методів державного управління в рекреаційній сфері в межах своїх повноважень. Існують тісні підпорядковані, координаційні зв'язки між цими організаційними структурами. Здійснено аналіз функціонального призначення основних інституційних акторів у рекреаційній сфері.

Визначено проблемні питання сучасного стану інституційного забезпечення механізмів державного регулювання розвитку рекреаційної сфери в 
Україні. Визначено, що складність їі регулювання полягає в тому, що в Україні відсутня чітка, уніфікована система державного регулювання рекреаційної сфери, тому певні іiї аспекти в нашій державі нині перебувають під контролем багатьох державних органів (міністерства, служби, агентства).

Підкреслено, що в системі державного управління рекреаційною сферою немає органу, що відповідає за проведення виключно функцій управління рекреаційними територіями; фактично усі органи державної влади мають функції управління відповідно до реакційних територій та рекреаційних ресурсів, поряд з функціями управління іншими ресурсами, об’єктами, територіями. Адміністративна діяльність органів влади спрямована на вирішення проблем організації, охорони рекреаційних територій та використання рекреаційних ресурсів тією мірою, що й для виконання інших завдань у різних сферах діяльності суспільства.

Викладено напрями оптимізації інституційного механізму державного регулювання розвитку рекреаційної сфери. Зазначено, що організаційноекономічний механізм має грунтуватися на формуванні регіональних інституцій, що дасть можливість концентрувати та координувати зусилля всіх суб'єктів рекреаційної діяльності з метою досягнення оптимального рівня рекреаційного потенціалу на регіональному рівні.

Ключові слова: рекреація, рекреаційна діяльність, інституційний механізм, організаційний механізм, державне регулювання, механізми державного регулювання.

\section{ОСОБЕННОСТИ ИНСТИТУЦИОНАЛЬНОГО ОБЕСПЕЧЕНИЯ МЕХАНИЗМОВ ГОСУДАРСТВЕННОГО РЕГУЛИРОВАНИЯ РАЗВИТИЯ РЕКРЕАЦИОННОЙ СФЕРЫ}

Аннотация. Систематизированы и уточнены теоретические основы исследования институционального обеспечения механизмов государственного регулирования развития рекреационной сферы.

Следует обратить внимание на то, что институциональную поддержку сектора рекреации формируют государственные и неправительственные организационные структуры, созданные на разных уровнях механизма, и реализуют свои решения с помощью методов государственного управления в рекреационной сфере в пределах своих полномочий. Существуют тесные подчиненные, координационные связи между этими организационными структурами. Проведен анализ функционального назначения основных институциональных актеров в рекреационной сфере.

Определены проблемные вопросы современного состояния институционального обеспечения механизмов государственного регулирования развития рекреационной сферы в Украине. Отмечено, что сложность ее регулирования заключается в том, что в Украине отсутствует четкая, унифицированная система государственного регулирования рекреационной сферы, поэтому некоторые ее аспекты в нашем государстве сейчас находятся под контролем многих государственных органов (министерства, службы, агентства). 
Было подчеркнуто, что в системе государственного управления рекреационной сферой нет органа, который отвечает за проведение исключительно функций управления рекреационными территориями; практически все органы государственной власти имеют функции управления по отношению к реакционным территориям и рекреационным ресурсам, наряду с функциями управления другими ресурсами, объектами, территориями. Административная деятельность органов власти направлена на решение проблем организации, охраны рекреационных территорий и использования рекреационных ресурсов в той же степени, что и для выполнения других задач в различных сферах деятельности общества.

Изложены направления оптимизации институционного механизма государственного регулирования развития рекреационной сферы. Отмечено, что организационно-экономический механизм должен базироваться на формировании региональных институтов, которые позволят концентрировать и координировать усилия всех субъектов рекреационной деятельности с целью достижения оптимального уровня рекреационного потенциала на региональном уровне.

Ключевые слова: рекреация, рекреационная деятельность, институциональный механизм, организационный механизм, государственное регулирование, механизмы государственного регулирования.

\section{FEATURES OF INSTITUTIONAL SUPPORT OF MECHANISMS OF STATE REGULATION OF RECREATION SPHERE DEVELOPMENT}

Abstract. The theoretical foundations in the research of institutional support of mechanisms of state regulation of recreational sphere development are systematized and specified.

Attention is drawn to the fact that the institutional support of the recreation sector is shaped by state and non-governmental organizational structures created at different levels of the mechanism and implementing their decisions through the methods of public administration in the recreational sphere within their powers. There are close subordination, coordination and coordination relationships between these organizational structures. The analysis of the functional purpose of the main institutional actors in the recreational sphere is carried out.

The problematic issues of the current state of institutional provision of mechanisms of state regulation of the recreational sphere development in Ukraine are determined. It is noted that the complexity of its regulation lies in the fact that in Ukraine there is not a clear, unified system of state regulation of the recreational sphere, and therefore certain aspects of it in our state are now under the control of many state bodies (ministries, services, agencies).

It was emphasized that in the system of state management of recreational sphere there is no body that is responsible for carrying out exclusively functions of management of recreational territories; in fact, all state authorities have management functions in relation to reactionary territories and recreational resources, 
along with functions of management of other resources, objects, territories . The administrative activity of the authorities is aimed at solving the problems of organization, protection of recreational territories and the use of recreational resources to the same extent as for the fulfillment of other tasks in various spheres of society's activity.

The directions of optimization of the institutional mechanism of state regulation of the recreational sphere development are outlined. It is noted that the organizational and economic mechanism should be based on the formation of regional institutions that would allow to concentrate and coordinate the efforts of all subjects of recreational activity in order to achieve the optimal level of recreational potential at the regional level.

Keywords: recreation, recreational activity, institutional mechanism, organizational mechanism, state regulation, mechanisms of state regulation.

Постановка проблеми. Характерною ознакою прогресивності структурних змін в економіці є розвиток сфери послуг і зростання ії частки у валовому внутрішньому продукті, що зумовлено загальною тенденцією підвищення життєвого рівня населення та його прагненням до постійного розширення можливостей щодо задоволення власних різноманітних потреб. Важливу роль у цьому процесі відіграє рекреаційна сфера, функціонування якої спрямоване, насамперед, на збереження й відновлення здоров'я, а також на надання широкого спектра додаткових послуг, пов'язаних з повноцінним і активним відпочинком громадян. Відтак рекреаційна сфера має складну структуру свого вияву в суспільному житті України, а тому для ефективного їі функціонування та розвитку потрібна державна координація і регулювання. Забезпечення умов для створення ефективної та узгодженої системи органів державного регулювання рекреаційної сфери України, на наш погляд, є важливим фактором стійкого їі соціально-економічного розвитку. Водночас саме інституційне забезпечення державного регулювання рекреаційної сфери відзначається складністю, суперечливістю i незавершеністю, що стримує іiі розвиток.

Аналіз останніх досліджень i публікацій. Дослідженню проблем державного регулювання рекреаційної сфери присвячені праці В. І. Бирковича, Н. Г. Білої, М. М. Білинської, В. Н. Василенка, Н. Р. Нижник, Д. В. Карамишева, С. І. Куща, В. П. Мегедь, Я. Ф. Радиша, О. І. Черниша, О. С. Шаптали, А. Donabedian, L. Forrest, C. Kaspar, J. Krippendorf та ін.

Проте значна частина досліджень з регулювання рекреаційної сфери не враховує специфіки та особливостей інституційного забезпечення механізмів державного регулювання розвитку рекреаційної сфери. Крім того, ця проблема не рзглядалася комплексно і не містила таких складових: наукове обгрунтування, фінансове, матеріально-техніч- 
не й нормативно-правове забезпечення.

\section{Формулювання цілей (мети)} статті. Метою статті є розроблення теоретичних основ та практичних підходів до удосконалення інституційного забезпечення механізмів державного регулювання розвитку рекреаційної сфери.

Виклад основного матеріалу. Визначаючи систему органів державного управління рекреаційною сферою, необхідно враховувати їх управлінську компетенцію у цій сфері. Тобто до органів державного управління рекреаційною сферою належать ті органи, які наділені державно-владними функціями з метою виконання поставлених перед ними завдань у сфері охорони рекреаційних територій та використання рекреаційних ресурсів, а ефективність управлінської діяльності залежить від повноти закріплення компетенції суб'єктів управління у законодавстві.

Серед органів державного управління рекреаційною сферою варто виділити Верховну Раду України, яка відіграє особливу роль в регулюванні відносин щодо охорони рекреаційних територій, оскільки вона у цій галузі наділена винятковою компетенцією. А саме, до відання Верховної Ради України, передусім, належить законодавче регулювання відносин у сфері охорони рекреаційних територій і використання рекреаційних ресурсів та визначення основних напрямів державної політики у цій галузі [1]. Виключними повноваженнями Верховної Ради України в галузі рекреації є: визначення основних напрямів державної політики в рекреаційній сфері; визначення пра- вових засад регулювання відносин у рекреаційній сфері, їх удосконалення та адаптація із загальновизнаними нормами міжнародного права; визначення в законі про Державний бюджет України обсягу фінансового забезпечення рекреаційної галузі [2].

Управлінськими функціями в галузі охорони рекреаційних територій та використання рекреаційних ресурсів наділений Кабінет Міністрів України. Так, уряд здійснює реалізацію визначеної Верховною Радою України екологічної політики, забезпечує розроблення регіональних екологічних програм. Також Кабінет Міністрів України приймає рішення про організацію територій та об'єктів природно-заповідного фонду загальнодержавного значення, тобто управлінська компетенція уряду у сфері охорони рекреаційних територій та використання рекреаційних ресурсів поширюється на рекреаційні зони, що входять до складу територій та об'єктів природно-заповідного фонду загальнодержавного значення (наприклад, на територіях національних природних парків виділяється зона регульованої рекреації та зона стаціонарної рекреації, біосферних заповідників - зона антропогенних ландшафтів тощо).

До того ж загальне керівництво діяльністю оздоровчо-лікувальними закладами здійснюється Кабінетом Міністрів України, спеціально уповноваженим центральним органом виконавчої влади 3 питань діяльності курортів, а також обласними і Київською міською державною адміністрацією, іншими органами виконавчої влади і місцевого самоуправління. 
Серед головних повноважень Кабінету Міністрів України у сфері діяльності курортів можна виділити: установлення норм і правил користування природними лікувальними ресурсами; організацію ведення державного обліку природних лікувальних ресурсів, лікувально-оздоровчих місцевостей і курортів; затвердження режиму округів і зон санітарної охорони курортів державного значення; затвердження порядку ведення моніторингу природних територій курортів і порядку створення та ведення Державного кадастру природних територій курортів України і Державного кадастру природних лікувальних ресурсів України [3].

Відтак Кабінет Міністрів України відповідно до Конституції та законів України: здійснює державне управління та забезпечує реалізацію державної політики в галузі рекреації; розробляє й затверджує програми розвитку рекреаційної сфери в Україні, фінансує їх виконання відповідно до бюджетного законодавства; приймає нормативно-правові акти, що регулюють відносини в галузі рекреаційної діяльності; забезпечує раціональне використання рекреаційних ресурсів і вжиття заходів для їх збереження; сприяє розвитку рекреаційної індустрії та створенню ефективної рекреаційної інфраструктури; організовує та забезпечує реалізацію державної інвестиційної політики в галузі рекреаційної діяльності; готує та подає на розгляд Верховної Ради України як складову проекту закону про Державний бюджет України на відповідний рік пропозиції щодо обсягів бюджетних коштів для фінансової підтримки проектів і програм з розвитку рекреації; інформує Верховну Раду України про виконання програми розвитку рекреації в Україні; створює державну систему наукового забезпечення в галузі рекреаційної діяльності тощо [4].

Реалізовуючи повноваження $\mathrm{y}$ рекреаційній сфері, зокрема стосовно охорони рекреаційних територій та використання рекреаційних ресурсів, Кабінет Міністрів України видає постанови і розпорядження, які є обов'язковими до виконання та мають нормативний, організаційно-упорядкувальний, компетенційно-установчий характер. Урядові акти спрямовані на врегулювання відносин, в яких безпосереднім об'єктом виступають як рекреаційні зони, що входять до складу інших територій та об'єктів, що підлягають охороні, так і рекреаційні території та рекреаційні ресурси.

Головним органом у системі центральних органів виконавчої влади, що забезпечує формування i peaлізує державну політику стосовно рекреаційної сфери є Міністерство екології та природних ресурсів України (Мінприроди), що здійснює свої управлінські функції відповідно до Закону України "Про охорону навколишнього природного середовища" та Положення про Міністерство екології та природних ресурсів України. Управлінська компетенція Мінприроди щодо рекреаційних територій є загальною, оскільки управління у сфері охорони рекреаційних територій та використання рекреаційних ресурсів Мінприроди здійснюе нарівні з управлінням використанням і охороною інших природних ресурсів, природних об'єктів і територій. 
Слід зауважити, що серед основних завдань Мінприроди не визначено завдань щодо охорони рекреаційних територій та використання рекреаційних ресурсів, лише загальні завдання: забезпечення раціонального використання, відтворення й охорони природних ресурсів, збереження, відтворення та невиснажливого використання біологічного та ландшафтного різноманіття, формування, збереження та використання екологічної мережі, організації, охорони та використання природно-заповідного фонду тощо. Більша ж частина повноважень Мінприроди у сфері охорони рекреаційних територій i використання рекреаційних ресурсів стосується рекреаційних зон, які входять до складу окремих територій та об’єктів природно-заповідного фонду.

У межах управлінської структури Мінприроди України функціонують центральні органи виконавчої влади, які також здійснюють регулювання рекреаційно-туристичної сфери, а саме Державна екологічна інспекція, Державна служба геології та надр України, Державне агентство водних ресурсів України, Державне агентство екологічних інвестицій України, Державне агентство України з управління зоною відчуження, Державне агентство екологічних інвестицій.

На особливу увагу в системі державних органів управління рекреаційними територіями заслуговує Державна екологічна інспекція (Держекоінспекція України), до компетенції якої зараховано функцію контролю щодо раціонального використання, відтворення та охорони природних ресурсів, зокрема природ- них рекреаційних ресурсів, додержання режиму територій та об'єктів природно-заповідного фонду, зокрема рекреаційних зон, що входять до їх складу.

Через міністра аграрної політики та продовольства Кабінет Міністрів України спрямовує і координує діяльність Державного агентства лісових ресурсів України (Держлісагентство). Держлісагентство є центральним органом виконавчої влади, який реалізує державну політику у сфері лісового та мисливського господарства. Щодо повноважень у сфері рекреації, то саме Держлісагентство приймає рішення про зарахування лісів до відповідної категорії. Адже лісові ділянки, що виконують рекреаційну, санітарно-гігієнічну та оздоровчу функції, використовуються для туризму, занять спортом, санаторно-курортного лікування та відпочинку населення, належать до категорії рекреаційно-оздоровчих лісів.

При цьому варто зауважити, що не всі питання, пов'язані з державним регулюванням рекреаційного природокористування, знаходяться в компетенції Міністерства екології та природних ресурсів, частина їх віднесена до повноважень центральних органів виконавчої влади, діяльність яких координує і спрямовує Міністерство аграрної політики та продовольства України.

Проте слід зазначити, що система державної рекреаційної політики України не вичерпується зазначеними інституціями. Складність іiі регулювання полягає в тому, що в Україні не створено чіткої, єдиної системи державного регулювання рекреацій- 
ної сфери і тому певні іiї аспекти на сьогодні в нашій державі перебувають в управлінні багатьох державних органів (міністерств, служб, агентств тощо).

Серед них треба виокремити такі міністерства: Міністерство соціальної політики України, Міністерство охорони здоров'я, Міністерство молоді та спорту України тощо. Адже саме в рамках їхніх повноважень: забезпечується реалізація державної політики у сфері охорони здоров'я, санітарного та епідемічного благополуччя населення, соціального захисту населення, загальнообов'язкового державного соціального страхування, пенсійного забезпечення, соціального обслуговування населення, колективно-договірного регулювання соціально-економічних інтересів працівників і роботодавців, розвитку соціального діалогу; здійснюється реалізація загальних правових, соціальних, економічних й організаційних основ фізичної культури і спорту в Україні та забезпечується і контролюється участь державних органів, посадових осіб, а також підприємств, установ, організацій незалежно від форм власності у зміцненні здоров'я громадян, досягненні високого рівня працездатності та довголіття засобами фізичної культури і спорту.

Важливою державною інституцією щодо регулювання певних аспектів рекреаційно-туристичної сфери є і Міністерство культури України. Міністерство в установленому порядку вносить пропозиції щодо формування державної політики в курортній галузі, забезпечує iï реалізацію, здійснює управління в цій галузі, а також міжгалузеву коорди- націю. Основними завданнями міністерства є участь у формуванні та забезпеченні реалізації державної політики в курортній галузі; розроблення та реалізація загальнодержавних програм розвитку курортів і туристично-рекреаційної сфери, ринку туристичних послуг, забезпечення захисту і безпеки туристів; визначення перспектив і напрямів розвитку рекреаційної сфери, розбудови матеріально-технічної бази рекреації; міжгалузева координація та функціональне регулювання з питань рекреації; організація та розвиток системи наукового, інформаційно-рекламного забезпечення туристично-рекреаційної та курортної сфери [2].

Суб'єкти державного управління рекреаційною сферою представлені також центральними органами виконавчої влади в особі Міністерства інфраструктури України та Державного агентства з туризму та курортів України, а також спеціалізованими управліннями при обласних державних адміністраціях.

На місцевому рівні управлінськими повноваженнями у сфері організації, охорони рекреаційних територій і використання рекреаційних ресурсів наділені місцеві державні адміністрації та органи місцевого самоврядування.

Зважаючи на подібне розмежування сфер впливу серед управлінської вертикалі, необхідно додати, що дані державні структури не в змозі контролювати увесь спектр відносин, що виникають у процесі рекреаційної діяльності в Україні. Також певну частку повноважень в управлінні рекреаційною сферою виконують: податкові інспекції на містах, 
менеджери та керівники суб’єктів рекреаційної діяльності, посередницькі фірми, суб'єкти реклами та зв'язку тощо. Тобто у певному розумінні, в сфері рекреаційних послуг задіяні суб’єкти та особи різних форм власності.

Слід зауважити, що діяльність структур держаного регулювання рекреаційної сфери на місцях також має подібні проблеми в регіонах. Це, передусім, залежить від нерозуміння самою місцевою владою значення рекреаційної сфери для розвитку місцевої економіки й необхідності регулювання на місцевому рівні та певною мірою зумовлено браком висококваліфікованих спеціалістів з питань рекреації як в органах місцевої влади, так і серед працівників сфери в регіоні.

У контексті розгляду цього питання варто наголосити, що в системі органів державного управління рекреаційної сфери немає органу, до компетенції якого належить здійснення винятково функцій управління рекреаційними територіями, фактично усі державні органи наділені управлінськими функціями щодо реакційних територій та рекреаційних ресурсів, поряд із функціями управління іншими ресурсами, об'єктами, територіями. Управлінська діяльність органів спрямована на вирішення завдань щодо організації, охорони рекреаційних територій та використання рекреаційних ресурсів тією ж мірою, що й на виконання інших завдань у різних сферах життєдіяльності суспільства.

До того ж в Україні спостерігаємо постійні реформи щодо зміни центрального органу загального дер- жавного рівня, до компетенцій якого належить управління рекреаційною галуззю. Вважаємо, що це явище украй негативне, адже часті реорганізації та перерозподіл повноважень між уже існуючими та новоствореними державними структурами нівелюють можливість системності у функціонуванні механізму державного управління рекреаційною галуззю на всіх управлінських рівнях.

У зв'язку з тим, що Україна проголошує рекреацію одним із пріоритетних напрямів розвитку економіки та культури і створює умови для рекреаційної діяльності, виникає нагальна потреба у проведенні структурних змін у системі органів державної влади, що здійснюють державне регулювання рекреаційної сфери на всіх рівнях. Причому вдосконалення органів державної влади, які здійснюють регулювання рекреаційної сфери на місцевому, регіональному та центральному рівнях повинно відбуватися в руслі удосконалення й інших гілок української влади.

Чіткий розподіл прав та обов'язків різних рівнів управління $є$ неодмінною умовою ефективності системи управління рекреаційною галуззю. Відтак ланка урядового управління рекреаційною діяльністю повинна забезпечувати: розроблення Концепції розвитку рекреаційної галузі, механізму ii впровадження та забезпечення процесу реалізації; оформлення та подання до Верховної Ради законотворчих ініціатив; підготовку і внесення пропозицій до Кабінету Міністрів стосовно координації міністерств і відомств із питань розвитку рекреаційної галузі, i iнфраструктури, матеріально-техніч- 
ної бази, підприємств рекреаційної сфери різновідомчого підпорядкування усіх форм власності; організацію нових рекреаційних зон; створення та забезпечення національної інформаційно-рекламної системи галузі; організацію рекламної діяльності за цільовими інвестиційними проектами у країні та за кордоном.

Функціями ланки обласного управління (відділів з рекреації) мають бути: функції контролю за якістю обслуговування рекреантів, ліцензування рекреаторів, сертифікацію засобів розміщення (готелів, кемпінгів, баз відпочинку), стимулювання розробок інноваційного туристично-рекреаційного продукту, нових форм обслуговування, пошук потенційних інвесторів.

Водночас, досліджуючи систему органів державного управління рекреаційною сферою, необхідно враховувати також рівень територіального поширення їхніх повноважень. Для невиснажливого використання рекреаційних ресурсів та охорони рекреаційних територій, передусім, необхідно забезпечити оптимальне співвідношення загальнодержавних і місцевих інтересів у створенні системи органів державного управління у цій сфері, адже саме місцеві органи найбільш поінформовані про проблеми місцевості та потреби населення, що дає змогу враховувати таку специфіку під час здійснення управлінських функцій.

Ефективне інституційне забезпечення має діяти на принципах прозорості, ефективності, економічності, оперативності та передбачати активну співпрацю з іншими структурами, зокрема недержавними, які зацікавлені в розвитку рекреаційної галузі. Основним завданням такого забезпечення повинно бути створення сприятливих умов для розвитку рекреаційної сфери. Тобто можемо виділити такі основні вимоги до побудови ефективного інституційного забезпечення механізму державного управління рекреаційною сферою: усунення дублювання i розмежування функцій у діяльності; спеціалізація й уніфікація функцій управління за рівнями та організаційно-господарськими ланками; скорочення і здешевлення витрат на утримання управлінського апарату; економічність, стійкість, гнучкість і надійність інституційної структури.

На місцевому рівні найвиразніше виявляється недосконалість організаційно-функціональної структури управління рекреаційною сферою. Малочисельні інспекційні підрозділи з низьким матеріально-технічним забезпеченням неспроможні повною мірою задовольняти потреби і вимоги суспільства щодо належного контролю за станом навколишнього середовища й підвищенням його якості. Виходячи з цього, організаційно-економічний механізм має грунтуватися на утворенні регіональних інституцій, які б дозволили сконцентрувати та узгодити зусилля всіх суб'єктів рекреаційної діяльності задля досягнення оптимального рівня використання рекреаційного потенціалу на рівні регіону. При цьому важливо скоординувати дії служб, які функціонують у сфері рекреації, створити єдину раціональну систему інформаційного забезпечення, систему контролю, аналізу та експертизи. 
Вирішення проблем, пов'язаних 3 інституційними засадами державного регулювання рекреаційної сфери, дасть змогу провести структурні зрушення в системі державної влади України з метою створення в державі цілісної системи державного регулювання рекреаційної сфери.

Висновки. Таким чином, інституційне забезпечення галузі рекреації формують державні та недержавні організаційні структури, які створені на різних рівнях механізму та реалізують свої рішення через методи державного управління в рекреаційній сфері в межах своїх повноважень. Між цими організаційними структурами існують тісні субординаційні, реординаційні та координаційні взаємозв’язки.

\section{СПИСОК ВИКОРИСТАНИХ ДЖЕРЕЛ}

1. Гаман П. Особливості функціонування механізму державного регулювання розвитку туризму на регіональному рівні / П. Гаман // Держава та регіони. - 2015. - № 2. C. 39-44.

2. Лазор О. Органи державного управління в галузі екології та природних ресурсів / О. Лазор // Вісн. УАДУ. - К. : УАДУ, 2011. - № 4. С. 195-202.
3. Розметова О. Теоретичні засади державного регулювання розвитку рекреаційно-оздоровчо-туристичного комплексу / О. Розметова // Держава та регіони. - 2017. - № 4. C. 183-188.

4. Черчик Л. Напрями удосконалення державного управління у сфері рекреаційного природокористування / Л. Черчик // Наук.-інформ. вісн. Акад. наук вищ. освіти України. - 2012. - № 2 (79). - С. 105112.

\section{REFERENCES}

1. Gaman P. (2015), "Features of functioning of the mechanism of state regulation of tourism development at the regional level", Derzhava ta rehiony, vol. № 2, p. 39-44.

2. Lazor O. (2011), "Bodies of state administration in the field of ecology and natural resources", Visnyk UADU, vol. № 4, p. 195-202.

3. Rosetovoy O. (2017), "Theoretical Basis of State Regulation of the Development of the Recreation-Health-Tourist Complex", Derzhava ta rehiony, vol. № 4, p. 183-188.

4. Cherchik L. (2012), "Directions of improvement of public administration in the field of recreational nature use", Nauk.-inform. visn. Akad. nauk vysch. osvity Ukrainy, vol. № 2 (79), p. 105112. 